\title{
Alcohol Enhances GABAergic Transmission to Cerebellar Granule Cells via an Increase in Golgi Cell Excitability
}

\author{
Mario Carta, Manuel Mameli, and C. Fernando Valenzuela \\ Department of Neurosciences, University of New Mexico Health Sciences Center, Albuquerque, New Mexico 87131
}

\begin{abstract}
Alcohol intoxication alters coordination and motor skills, and this is responsible for a significant number of traffic accident-related deaths around the world. Although the precise mechanism of action of ethanol (EtOH) is presently unknown, studies suggest that it acts, in part, by interfering with normal cerebellar functioning. An important component of cerebellar circuits is the granule cell. The excitability of these abundantly expressed neurons is controlled by the Golgi cell, a subtype of GABAergic interneuron. Granule cells receive GABAergic input in the form of phasic and tonic currents that are mediated by synaptic and extrasynaptic receptors, respectively. Using the acute cerebellar slice preparation and patch-clamp electrophysiological techniques, we found that ethanol induces a parallel increase in both the frequency of spontaneous IPSCs and the magnitude of the tonic current. EtOH (50 mM) did not produce this effect when spontaneous action potentials were blocked with tetrodotoxin. Recordings in the loose-patch cell-attached configuration demonstrated that ethanol increases the frequency of spontaneous action potentials in Golgi cells. Taken together, these findings indicate that ethanol enhances GABAergic inhibition of granule cells via a presynaptic mechanism that involves an increase in action potential-dependent GABA release from Golgi cells. This effect is likely to have an impact on the flow of information through the cerebellar cortex and may contribute to the mechanism by which acute ingestion of alcoholic beverages induces motor impairment.
\end{abstract}

Key words: ligand gated; neurotransmitter; release; channel; ethanol; inhibitory

\section{Introduction}

Granule cells are the most abundant neuronal subtype in the cerebellar cortex. These glutamatergic neurons receive sensory input from mossy fibers and relay it to Purkinje neurons via the parallel fibers (see Fig. $1 A$ ). Mossy fiber input is filtered at granule cells by GABAergic inhibitory transmission, which profoundly modulates cerebellar information storage capacity (Tyrrell and Willshaw, 1992). Golgi interneurons provide tonic and phasic GABAergic input to granule cells. The presence of a tonic GABAergic current in granule cells was first described by Kaneda et al. (1995), who found a bicuculline-sensitive background noise current that persisted in the presence of glutamate antagonists, tetrodotoxin (TTX), or zero $\left[\mathrm{Ca}^{2+}\right]_{\mathrm{o}}$. This current originates from activation of high-affinity $\mathrm{GABA}_{\mathrm{A}}$ receptors by low levels of GABA derived from spillover of synaptically released transmitter that accumulates at extrasynaptic sites (Rossi et al., 2003). A factor that permits accumulation of GABA is the anatomical characteristics of the synapse between Golgi and granule cells. This synapse forms part of a glomerulus that contains four elements: (1) the mossy fiber terminal, (2) the Golgi cell axon, (3) the granule cell dendrites, and (4) a glial sheath (Rossi and Hamann, 1998). The latter confines released GABA to the glomerulus, in-

Received Jan. 7, 2004; revised Feb. 28, 2004; accepted March 3, 2004.

This work was supported by grants from the National Institute of Alcohol Abuse and Alcoholism. We thank D. Partridge for critically reading this manuscript.

Correspondence should be addressed to Dr. C. Fernando Valenzuela, Department of Neurosciences, MSC08 4740, 1 University of New Mexico, Albuquerque, NM 87131-0001. E-mail: fvalenzuela@salud.unm.edu.

DOI:10.1523/JNEUROSCI.0067-04.2004

Copyright $\odot 2004$ Society for Neuroscience $\quad$ 0270-6474/04/243746-06\$15.00/0 creasing the likelihood that it activates extrasynaptic receptors. In addition to this anatomical factor, the unique subunit composition of extrasynaptic $\mathrm{GABA}_{\mathrm{A}}$ receptors present in cerebellar granule cells makes them ideal mediators of tonic currents generated by background levels of GABA (Hamann et al., 2002). These receptors contain $\alpha_{6} \beta \delta$ subunits that have $\mathrm{GABA} \mathrm{EC}_{50}$ values in the submicromolar range and undergo relatively little desensitization (Saxena and Macdonald, 1996; Wallner et al., 2003). Granule cells also receive phasic GABAergic inhibition in the form of IPSCs produced by conventional action potential- and $\mathrm{Ca}^{2+}$. dependent vesicular GABA release from Golgi interneurons. These phasic currents superimpose on the background tonic current and are thought to be important for controlling synchronous rhythmic firing of these neurons (Hamann et al., 2002).

Cerebellar neuronal circuits are involved in the control of the motor systems. EtOH at concentrations $\geq 0.08 \mathrm{gm} / \mathrm{dl}(\sim 17 \mathrm{~mm})$ significantly impairs motor skills, and this is responsible for a significant number of traffic accident-related deaths. Individuals with low sensitivity to this action of EtOH are more likely to develop alcoholism (Schuckit et al., 1994). Therefore, understanding the mechanism of action of EtOH in the cerebellum is an area of tremendous interest. Most studies of the effects of EtOH on the function of cerebellar circuits have focused on Purkinje neurons (Deitrich et al., 1989; Palmer and Hoffer, 1990; Lin et al., 1991, 1993, 1994; Lee et al., 1995; Freund and Palmer, 1997; Yang et al., 1999, 2000); however, little is known about its effects on synaptic transmission at cerebellar granule cells. Using acute cerebellar slices and patch-clamp electrophysiological techniques, we demonstrate here that $\mathrm{EtOH}$ indirectly enhances GABAergic transmission to cerebellar granule cells via an in- 


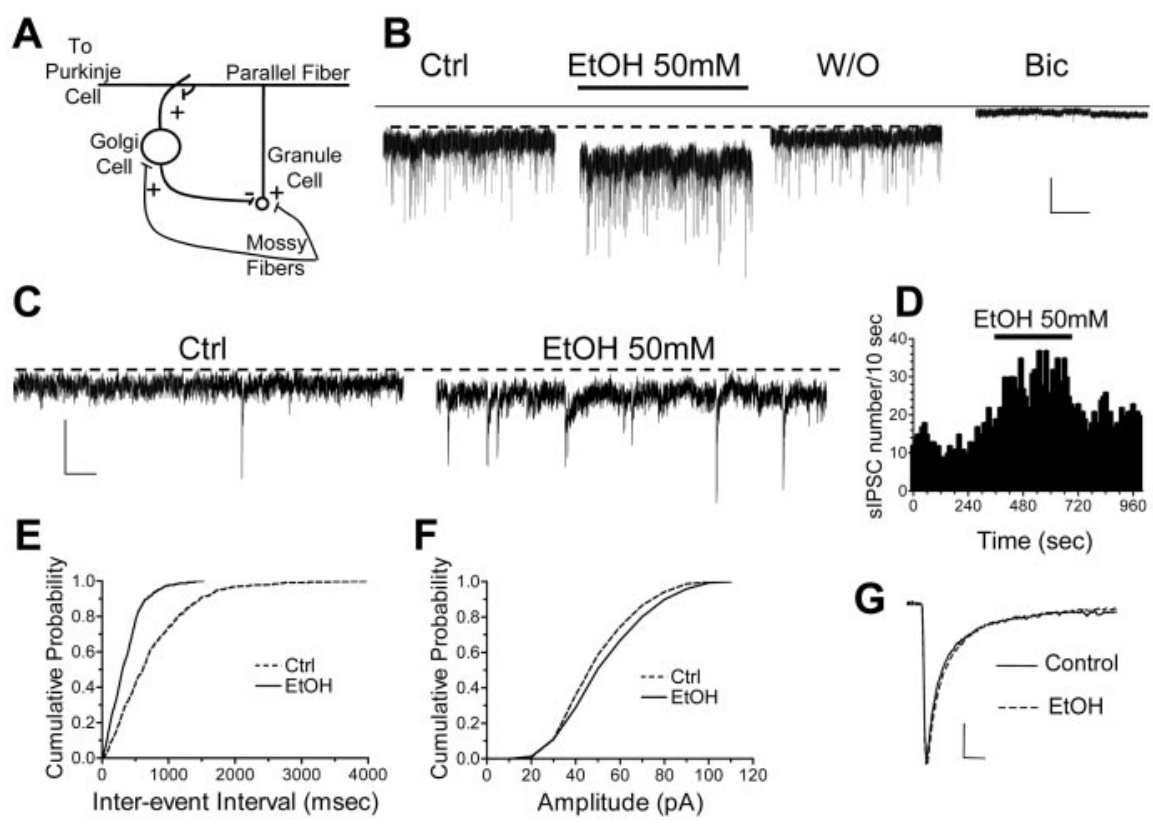

Figure 1. EtOH increases GABAergic transmission to granule cells. A, Simplified representation of the basic cerebellar cortical circuit. For clarity, we show only the components of the circuit that are relevant to this study. Mossy fibers, which come from the spinal cord and brain stem, provide excitatory input to granule and Golgi cells. Granule cells receive inhibitory input from Golgi cells. Granule cells provide excitatory input to Purkinje cells and Golgi cells via the parallel fibers. $B$, Sample traces of GABAergic currents recorded from a cerebellar granule neuron before (control; $\mathrm{Ctrl}$ ) and during application of $50 \mathrm{~mm}$ EtOH and after washout (W/O). Note that EtOH induced a reversible increase in sIPSCs frequency, an inward current shift, and an increase in background noise. GABAergic currents were blocked by bicuculline (20 $\mu \mathrm{m})$. Calibration: 40 pA, $10 \mathrm{sec}$. C, Expanded time scale sIPSC traces illustrating that these events can be clearly distinguished from background noise. Calibration: $50 \mathrm{pA}, 200 \mathrm{msec}$. D, Frequency histogram corresponding to the recording shown in $B$, illustrating the effect of $\mathrm{EtOH}$ on sIPSC frequency as a function of time. $E$, Cumulative probability frequency histograms corresponding to the recording shown in $B$. F, Same as in $E$ but for amplitude. $G$, Average sIPSC traces obtained from the recording shown in $B$. Calibration: 10 pA, 5 msec. Note that EtOH does not affect the amplitude or decay of these currents.

crease in action potential-dependent GABA release from Golgi interneurons.

\section{Materials and Methods}

Unless indicated, all chemicals were from Sigma (St. Louis, MO). Experiments were performed in parasagittal vermis cerebellar slices that were prepared from 30- to 45-d-old male Sprague Dawley rats. Animals were anesthetized with $250 \mathrm{mg} / \mathrm{kg}$ ketamine, and 200 - to $250-\mu \mathrm{m}$-thick slices were prepared with avibratome as described (Shuttleworth and Connor, 2001). Artificial CSF (ACSF) contained (in mM): $126 \mathrm{NaCl}, 3 \mathrm{KCl}, 1.25$ $\mathrm{NaH}_{2} \mathrm{PO}_{4}, 1 \mathrm{MgSO}_{4}, 26 \mathrm{NaHCO}_{3}, 2 \mathrm{CaCl}_{2}$, and 10 glucose equilibrated with $95 \% \mathrm{O}_{2}$ plus $5 \% \mathrm{CO}_{2}$. When indicated, bicuculline methiodide, GYKI-53655 (custom synthesized by Tocris-Cookson, Bristol, UK), DLAP5, TTX, or EtOH (AAPER Chemical Co., Shelbyville, KY) was added to the ACSF. After a recovery time of $\geq 80 \mathrm{~min}$, slices were transferred to a chamber perfused with ACSF at a rate of $2-3 \mathrm{ml} / \mathrm{min}$. Whole-cell and loose-cell-attached patch-clamp electrophysiological recordings from cerebellar granule cells and Golgi cells were performed under infrareddifferential interference contrast microscopy at $31^{\circ} \mathrm{C}$ with an Axopatch 200B amplifier (Axon Laboratories, Union City, CA). Patch pipettes had resistances of 3-5 M $\Omega$. Granule cells were identified on the basis of their location in the granule layer and their small size (capacitance: $<5 \mathrm{pF}$ ). Moreover, they lacked spontaneous firing in the cell-attached mode and had high input resistances as well as monoexponentialcapacitive transients in response to ahyperpolarizing voltage step. Golgi cells were also located in the granule layer but had a considerably larger size (capacitance: $20-30 \mathrm{pF}$ ) and spontaneously fired regular action potentials in the loose-patch cell-attached configuration. To verify our cell identification criteria, we also recorded in the current-clamp whole-cell configuration from some of these putative Golgi cells. As expected, we found that Golgi cells responded to a hyperpolarizing current injection with a "sag" un- derling the activation of an $I_{\mathrm{h}}$ current and also displayed a bi-exponential capacitive transient in response to a hyperpolarizing voltage step (data not shown) (Dieudonne, 1995, 1998). We performed whole-cell recordings of GABAergic currents at a holding potential of $-65 \mathrm{mV}$ using internal solution containing (in $\mathrm{mm}$ ): $140 \mathrm{CsCl}$, $2 \mathrm{MgCl}_{2}, 1 \mathrm{CaCl}_{2}, 10$ EGTA, 10 HEPES, pH 7.3, $2 \mathrm{Na}_{2}$-ATP, and 4 QX-314 (Tocris-Cookson). Whole-cell recordings of spontaneous EPSCs (sEPSCs) were performed at a holding potential of $-65 \mathrm{mV}$ with an internal solution containing (in mM): 110 Cs-Gluconate, $5 \mathrm{NaCl}, 10 \mathrm{TEA}-\mathrm{Cl}$, 4 Mg-ATP, 0.6 EGTA, 10 HEPES, pH 7.25, and 4 QX-314. Access resistances were between 20 and $35 \mathrm{M} \Omega$; if access resistance changed $>20 \%$, the recording was discarded. Loose-patch cellattached (15-200 M $\Omega$ ) recordings were performed from the soma of visually identified Golgi cells using regular ACSF in the recording electrode. This technique has been used previously to obtain stable long-lasting recordings and to minimize the dialysis of intracellular components via the patch pipette (Kondo and Marty, 1998). Data were acquired with pClamp-8 (Axon Laboratories) and analyzed with pClamp-8 and Minis Analysis program (Synaptosoft, Decatur, GA). For the analysis of tonic GABAergic currents, we selected epochs of $3 \mathrm{sec}$ every $30 \mathrm{sec}$ of recording. We visually excluded sIPSCs from the analysis of tonic currents. For the analysis of sIPSCs, we visually selected each event. As shown in Figure 1C, sIPSCs can be clearly distinguished from the background noise on the basis of their fast rise times and slower decay times. Evoked IPSCs (eIPSCs) were elicited with a concentric bipolar stimulating electrode placed 100-200 $\mu \mathrm{m}$ from the patched granule cell. We used a stimulation frequency of $0.05 \mathrm{~Hz}$. Each slice was exposed once to a single EtOH concentration. The effect of ethanol was quantified with respect to the average of control and washout responses. The Kolmogorov-Smirnov test was used initially to test for significant differences between treatments in individual cells. Statistical analyses of pooled data were performed by one-sample $t$ test versus a theoretical mean of zero or 100. Data are presented as mean \pm SEM.

\section{Results}

We initially studied the effect of EtOH on GABAergic input to cerebellar granule cells (Fig. $1 A$ ). In agreement with previous reports, we found that these cells display a tonic GABAergic current that is abolished by bicuculline (Fig. 1 B) (Kaneda et al., 1995; Tia et al., 1996; Rossi and Hamann, 1998; Hamann et al., 2002). The average size of the outward current induced by $20 \mu \mathrm{M}$ bicuculline (I Bic) was $46 \pm 3 \mathrm{pA}(n=42)$. Moreover, the tonic current was reduced by a concentration of furosemide $(100 \mu \mathrm{M})$ that selectively antagonizes $\mathrm{GABA}_{\mathrm{A}}$ receptors containing $\alpha_{6}$ subunits; tonic current noise variance was reduced by $43 \pm 3 \%$ with respect to control ( $n=7$; data not shown).

Under our recording conditions, we detected sIPSCs with an average frequency of $0.85 \pm 0.15 \mathrm{~Hz}(n=39)$ that were superimposed on the tonic current (Fig. $1 B, C$ ). Application of $50 \mathrm{~mm}$ EtOH for 5 min induced a reversible increase in sIPSC frequency (Fig. $1 B-E$ ); however, we did not detect an effect of EtOH on the amplitude or decay of these events (Fig. $1 F, G$ ). The increase in sIPSC frequency was accompanied by an increase in the tonic current (Fig. $1 B)$. EtOH $(50 \mathrm{~mm})$ induced an average inward current shift of $8 \pm 1 \mathrm{pA}(n=9)$. Importantly, EtOH did not 

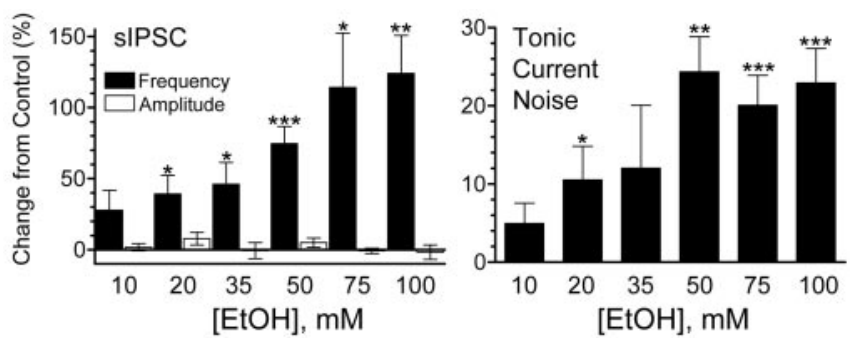

Figure 2. Effect of increasing concentrations of EtOH on sIPSCs and tonic current. Left, Summary of the effect of $10 \mathrm{~mm}(n=5), 20 \mathrm{~mm}(n=6), 35 \mathrm{~mm}(n=6), 50 \mathrm{~mm}(n=9), 75 \mathrm{~mm}(n=$ $6)$, and $100 \mathrm{~mm}(n=9) \mathrm{EtOH}$ on sIPSC frequency and amplitude. Note the lack of an effect of $\mathrm{EtOH}$ on amplitude even at a concentration of $100 \mathrm{~mm}$. Right, Summary of the effect of $10 \mathrm{~mm}$ $(n=6), 20 \mathrm{~mm}(n=7), 35 \mathrm{~mm}(n=7), 50 \mathrm{~mm}(n=14), 75 \mathrm{~mm}(n=8)$, and $100 \mathrm{~mm}(n=6)$ $\mathrm{EtOH}$ on the tonic current noise variance. ${ }^{*} p<0.05$; ${ }^{* *} p<0.005$; ${ }^{* * *} p<0.0005$, by onesample $t$ test versus theoretical mean of zero.

induce a current shift in the presence of bicuculline (change in holding current was $0.04 \pm 0.8 \mathrm{pA} ; n=4$; data not shown).

Figure 2 shows the effect of increasing concentrations of EtOH on GABAergic transmission at granule cells. Pooled data shown in the left panel indicate that EtOH significantly increased sIPSC frequency but not amplitude; the minimal concentration for observing a significant effect of EtOH on sIPSC frequency was 20 $\mathrm{mM}$. Analysis of cumulative probability distributions of individual cells by means of the Kolmogorov-Smirnov test revealed a statistically significant $(p<0.05)$ effect of EtOH on sIPSC frequency in three of five (10 mM), four of six $(20 \mathrm{mM})$, five of six ( 35 $\mathrm{mM})$, eight of nine (50 mM), six of six ( $75 \mathrm{~mm})$, and nine of nine $(100 \mathrm{~mm})$ cells. The minimal concentration for inducing a change in tonic current noise variance was also $20 \mathrm{~mm}$. At $35 \mathrm{~mm}$, the effect of EtOH did not reach statistical significance because of high variability, but there was a clear increase in tonic current noise variance in four of seven cells tested.

We next tested the effect of ethanol on eIPSCs. In agreement with a previous report, we found that granule cell IPSCs evoked by Golgi cell stimulation have a rapid rise phase followed by a biphasic decay phase (Fig. 3A) (Hamann et al., 2002). The peak of these events is mainly mediated by receptors containing $\alpha_{1}$ subunits. The early decay phase $\left(30 \mathrm{msec}\right.$ ) is mediated by $\alpha_{1}$ and $\alpha_{6}$ subunit-containing receptors, whereas the late phase (200 msec; spillover phase) is mediated by $\alpha_{6}$ subunit-containing receptors (Hamann et al., 2002). As shown in Figure 3, EtOH (50 mM) affected neither the peak nor the decay phases of these events. As expected, inhibition of $\alpha_{6}$ subunit-containing receptors with 100 $\mu \mathrm{M}$ furosemide reduced both the early and spillover decay phases; the effect of furosemide on the early phase did not reach statistical significance because of high variability, but there was a clear inhibitory effect in 9 of 10 cells tested (Fig. 3) (Hamann et al., 2002). Bicuculline $(20 \mu \mathrm{M})$ abolished the eIPSCs $(n=5$; data not shown).

We next determined whether the EtOH-induced enhancement of GABAergic transmission was dependent on spontaneous action potential firing (Fig. 4). Application of TTX $(0.5 \mu \mathrm{M})$ significantly decreased the frequency, but not the amplitude, of sIPSCs; the relatively infrequent events that remain correspond to miniature IPSC (mIPSCs) (Fig. 4A, B). Moreover, the reduction in sIPSC frequency was associated with significant decreases in the tonic current amplitude and tonic current noise variance (Fig. $4 A, C)$. Importantly, neither 50 nor $100 \mathrm{~mm} \mathrm{EtOH}$ induced a significant change in the tonic current amplitude, noise variance, or mIPSC amplitude (Fig. $4 A, D$ ); however, mIPSC frequency
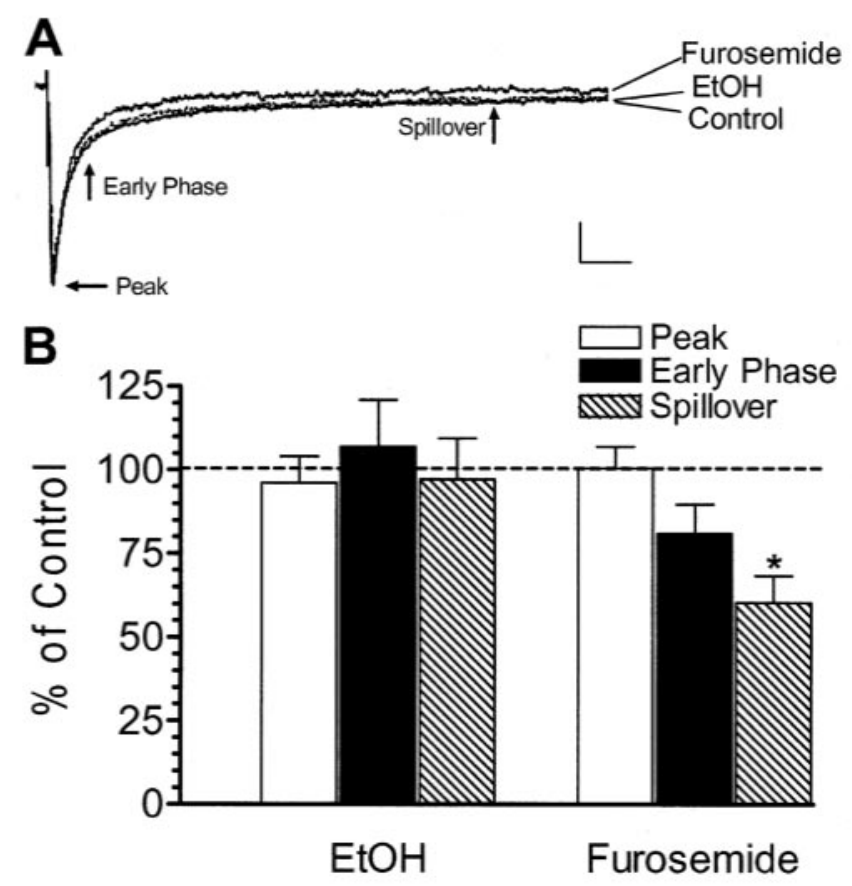

Figure 3. EtOH does not affect evoked IPSCs recorded in cerebellar granule cells. A, Sample traces of IPSCs evoked in a cerebellar granule cell by Golgi cell stimulation under control conditions, in the presence of $50 \mathrm{~mm} E \mathrm{EtOH}$ and in the presence of $100 \mu \mathrm{m}$ furosemide. The arrows indicate the peak, early phase ( $30 \mathrm{msec})$, and spillover phase $(200 \mathrm{msec})$. Calibration: $50 \mathrm{pA}, 25$ msec. $B$, Summary graph illustrating the lack of an effect of $50 \mathrm{~mm}$ EtOH on sIPSC peak amplitude, early decay phase, and spillover phase $(n=11)$. As expected, furosemide inhibited both decay phases, given that these are mediated by $\alpha_{6}$ subunit-containing receptors $(n=10)$; the effect of furosemide on the early phase did not reach statistical significance because of high variability, but there was a clear inhibitory effect in 9 of 10 cells tested. ${ }^{*} p<0.01$; by onesample $t$ test versus theoretical mean of 100 .

was significantly increased by $100 \mathrm{~mm} \mathrm{EtOH} \mathrm{(Fig.} \mathrm{4D).} \mathrm{This} \mathrm{find-}$ ing indicates that anesthetic concentrations of $\mathrm{EtOH}$ can increase the probability of GABA release at Golgi cell axonal terminals.

We then directly assessed the effect of $\mathrm{EtOH}$ on the firing rate of Golgi cells (Fig. 5). For these experiments, action potentials were recorded in the loose-patch cell-attached configuration (Kondo and Marty, 1998). This method allowed long-lasting recordings without perturbing the cytoplasmic contents. We found that under control conditions, Golgi cells fired with an average frequency of $9.3 \pm 1.7 \mathrm{~Hz}(n=13)$. After recording a stable baseline for $6 \mathrm{~min}$, application of $50 \mathrm{~mm} \mathrm{EtOH}$ induced a reversible increase in spontaneous action potential firing frequency (Fig. 5). On average, $50 \mathrm{~mm} \mathrm{EtOH}$ increased the firing frequency by $25 \pm 8 \%$ with respect to control ( $p<0.01$ by one-sample $t$ test vs a theoretical mean of zero; $n=13)$.

To determine whether EtOH selectively affects GABAergic inhibitory input to the granule cells, we also tested its action on glutamate release from mossy fibers. We recorded sEPSCs from granule cells in the whole-cell patch-clamp configuration; these events were blocked by $30 \mu \mathrm{M}$ GYKI-53655 and $100 \mu \mathrm{M}$ DL-AP5, indicating that they are mediated by AMPA and NMDA receptors $(n=3$; data not shown). As shown in Figure 6, $50 \mathrm{~mm} \mathrm{EtOH} \mathrm{did}$ not affect either the frequency or the amplitude of these events.

\section{Discussion}

We demonstrate here that EtOH increases GABAergic transmission at cerebellar granule cells. EtOH increased the tonic GABAergic current that mediates as much as $75 \%$ of the inhibi- 
A

Ctrl $\quad$ TTX EtOH 50mM

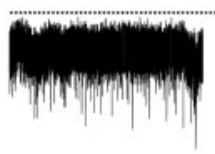

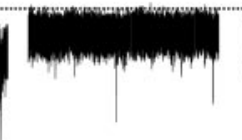
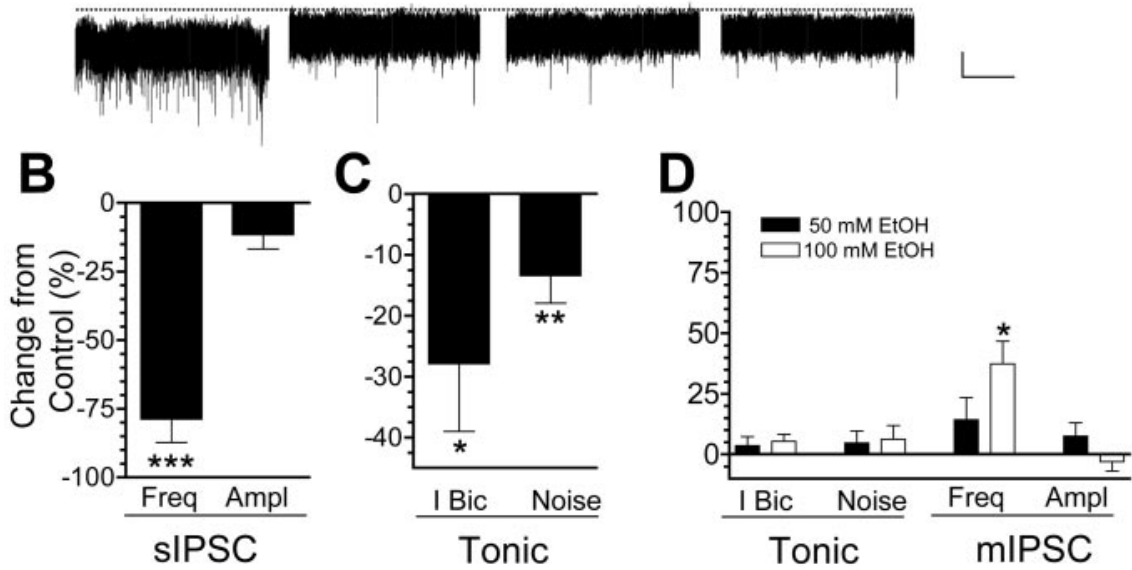

Figure 4. The EtOH-induced increase of GABAergic transmission to a cerebellar granule cell is blocked by TTX. A, Sample GABAergic current traces from a cerebellar granule neuron. Application of TTX dramatically reduced IPSC frequency and also reduced both the tonic current amplitude and noise variance. Note that in the presence of TTX, application of $50 \mathrm{~mm}$ EtOH did not affect mIPSC frequency or amplitude and did not change tonic current amplitude or current noise. All of the currents were blocked by the $\mathrm{GABA}_{\mathrm{A}}$ receptor antagonist bicuculline $(20 \mu \mathrm{m})$. Calibration: $25 \mathrm{pA}, 10 \mathrm{sec}$. B, Summary of the effect of TTX on sIPSC frequency and amplitude $(n=10)$. C, Summary of the effect of TTX on the amplitude of the tonic current (IBic; $n=16)$ and noise variance $(n=21)$. $D$, Summary of the effect of 50 and $100 \mathrm{~mm} \mathrm{EtOH}$ in the presence of TTX on the amplitude of the tonic current (I Bic; $n=10-11)$, tonic current noise $(n=11-14)$, and mIPSC frequency and amplitude $(n=4-6) .{ }^{*} p<0.03 ;{ }^{* *} p<0.008$; ${ }^{* * *} p<0.0005$, by one-sample $t$ test versus theoretical mean of zero.
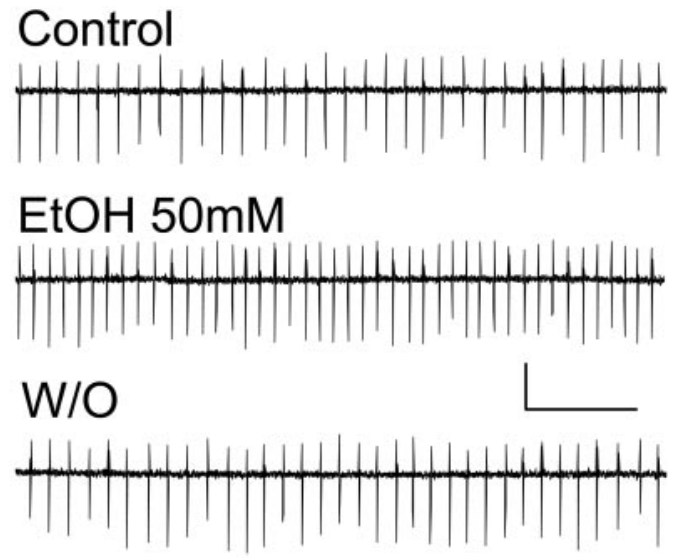

Figure 5. EtOH increases the spontaneous firing of Golgi cells. Sample traces of loose-patch cell-attached recordings illustrating that application of $50 \mathrm{~mm}$ EtOH induces a reversible increase in the frequency of spontaneous action potentials. Calibration: $40 \mathrm{pA}, 400 \mathrm{msec}$. EtOH increased the firing frequency by $25 \pm 8 \%$ with respect to control ( $p<0.01$ by one-sample $t$ test vs a theoretical mean of zero; $n=13$ ).

tion of these cells (Hamann et al., 2002). Indeed, a furosemideinduced reduction of the tonic current increases the number of action potentials elicited in granule cells by mossy fiber stimulation, resulting in an increase in Purkinje cell excitability (Hamann et al., 2002). Consequently, the flow of information through the mossy fiber-granule cell-Purkinje cell pathway is significantly increased when tonic GABAergic currents are reduced in granule cells; however, little is known regarding the potential impact of decreasing the flow of information through the cerebellar cortex via an increase in GABAergic inhibition of granule cells. Because the activity of these cells must be maintained within certain bounds for proper motor functioning (Watanabe et al., 1998), this is likely to have a deleterious effect.
Computer modeling studies indicate that an increase in tonic GABAergic currents should decrease synchronized oscillatory activity between populations of Golgi and granule cells (Maex and Schutter, 1998). It will be important to determine whether EtOH indeed alters this oscillatory activity, which could affect plasticity at parallel fiber-to-Purkinje cell synapses and alter Purkinje cell activity timing (Maex and Schutter, 1998).

Results obtained in several laboratories consistently indicate that the tonic GABAergic current of granule cells is essentially insensitive to TTX, suggesting that it is evoked mainly by ambient levels of GABA (Hamann et al., 2002; Rossi et al., 2003). Some studies, however, have found that blockade of action potentialdependent GABA release causes a slight reduction in the tonic current (Kaneda et al., 1995; Wall and Usowicz, 1997). We found a similar result using rats in the same age range, confirming that a component of the tonic current is mediated by spillover of synaptically released GABA that is triggered by spontaneous action potentials originating at Golgi cells. Our results strongly suggest that the mechanism of action of EtOH involves a selective increase in this component. $\mathrm{EtOH}(50 \mathrm{~mm})$ increased the tonic current and sIPSC frequency in parallel, and this effect was abolished by TTX. The most parsimonious explanation for these results is that EtOH increases action potential-dependent GABA release via an increase in Golgi cell excitability. Our finding that EtOH increased the frequency of spontaneous action potential firing in Golgi cells further supports this conclusion. It is noteworthy that a TTX-sensitive component of the tonic current has not been detected in all studies (Hamann et al., 2002; Rossi et al., 2003). This could be because of differences in Golgi cell excitability or viability, or both, related to the use of distinct slice preparation methods. To prepare cerebellar slices, we used ketamine for anesthesia and a sucrose-based solution also containing ketamine to provide additional neuroprotection (Aitken et al., 1995; Shuttleworth and Connor, 2001). These conditions should be particularly favorable for the preservation of GABAergic interneuron viability (Kuenzi et al., 2000), which, as indicated by our data with TTX, is a requirement for observing the effects of EtOH on the tonic current.

Our finding that EtOH does not affect the tonic current in the presence of TTX rules out several alternative mechanisms of action. First, it is unlikely that EtOH enhanced the tonic current by inhibiting GABA transporters. Rossi et al. (2003) showed that the GAT-1 and GAT-3 transporters are indeed active at cerebellar granule cell synapses and that inhibitors of these transporters increase the tonic current. Importantly, the action potentialdependent component of the tonic current is not required to observe the effect of transport inhibition (Rossi et al., 2003). Therefore, if EtOH acted by inhibiting these transporters, its effect should have persisted in the presence of TTX. Second, the results obtained with TTX argue against the possibility that EtOH increases the tonic current by directly potentiating the function of extrasynaptic $\mathrm{GABA}_{\mathrm{A}}$ receptors. This is somewhat surprising given that two recent studies using Xenopus oocytes found that 


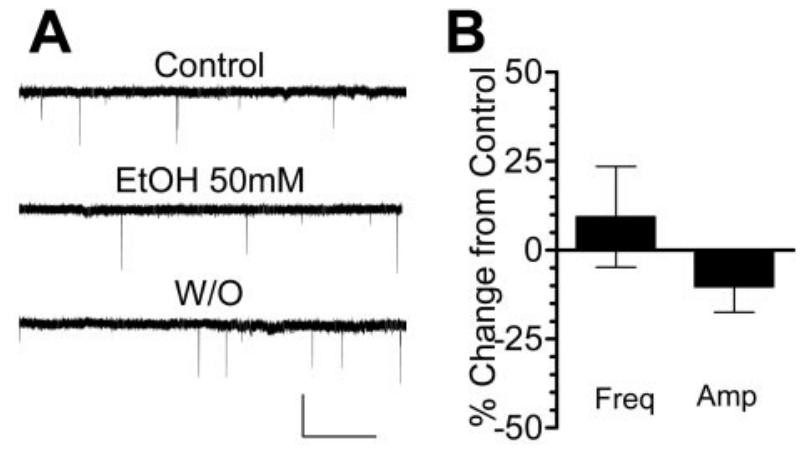

Figure 6. EtOH does not affect glutamatergic transmission at mossy fiber-to-granule cell synapses. A, Sample traces of sEPSC recordings from cerebellar granule neurons obtained in the presence of bicuculline $(20 \mu \mathrm{m})$ showing that application of $50 \mathrm{~mm}$ EtOH did not significantly affect the frequency or amplitude of these events. Calibration: $40 \mathrm{pA}, 5 \mathrm{sec}$. B, Summary of the effect of $50 \mathrm{~mm}$ EtOH on the frequency and amplitude of $s \operatorname{ESSCS}(n=5)$.

receptors containing the $\delta$ subunit are potently modulated by EtOH. Sundstrom-Poromaa et al. (2002) reported that receptors containing $\alpha_{4} \beta_{2} \delta$ subunits are significantly potentiated by $1-3$ $\mathrm{mm}$ EtOH. Wallner et al. (2003) also found that EtOH enhances the function of these receptors but at concentrations $\geq 30 \mathrm{mM}$; a similar result was obtained with $\alpha_{6} \beta_{2} \delta$ receptors (Wallner et al., 2003). Importantly, $\alpha_{4} \beta_{3} \delta$ and $\alpha_{6} \beta_{3} \delta$ receptors were significantly potentiated by EtOH concentrations $\geq 3 \mathrm{~mm}$ (Wallner et al., 2003). Given that receptors containing $\alpha_{6} \beta \delta$ subunits mediate the GABAergic tonic current of cerebellar granule cells (Hamann et al., 2002), we expected to detect a postsynaptic effect of EtOH; i.e., an increase in tonic current amplitude or noise variance, or both, in the presence of TTX. We also anticipated observing potentiation by EtOH of both the early and spillover decay phases of eIPSCs, which are mediated by receptors containing $\alpha_{6} \delta$ subunits (Hamann et al., 2002); however, an uncertainty that must be kept in mind is that the subunit composition of native receptors in cerebellar granule cells is more complex than that of the recombinant receptors studied by Wallner et al. (2003). Extrasynaptic receptors may contain more than one $\alpha$ or $\beta$ subunit subtype (Sigel and Baur, 2000), which could reduce their sensitivity to EtOH. Indeed, receptors containing $\alpha_{1} \alpha_{6} \delta$ subunits plus $\beta_{1}, \beta_{2}$, or $\beta_{3}$ subunits were recently identified in the rat cerebellum (Poltl et al., 2003). Moreover, functional studies have shown that modulation of postsynaptic $\mathrm{GABA}_{\mathrm{A}}$ receptors by $\mathrm{EtOH}$ depends on factors other than subunit composition. For instance, protein kinase $\mathrm{C}$ - or protein kinase A-dependent phosphorylation is required under some experimental conditions for the EtOHinduced potentiation of these receptors (Weiner et al., 1994, 1997; Harris et al., 1995; Freund and Palmer, 1997). The phosphorylation state of recombinant receptors expressed in Xenopus oocytes is expected to be different from that of native receptors present in granule cells. In addition, association with certain neuronal-specific proteins could decrease the sensitivity to EtOH of native receptors. Therefore, we cannot completely eliminate the possibility that EtOH directly modulates extrasynaptic receptors in cerebellar granule cells under some experimental conditions; however, our data clearly indicate that one of the mechanisms by which EtOH modulates inhibitory transmission at cerebellar granule cells is indirect via an increase in action potential-dependent GABA release from Golgi cells. It should be emphasized that our finding that $\mathrm{EtOH}$ does not affect the amplitude of eIPSCs, sIPSCs, or mIPSCs also indicates that it lacks a direct effect on $\alpha_{1}$ subunit-containing $\mathrm{GABA}_{\mathrm{A}}$ receptors.
The mechanism of the EtOH-induced increase in Golgi cell excitability could be direct or indirect. For instance, EtOH could directly affect Golgi cell firing by inhibiting potassium currents that contribute to the afterhyperpolarization phase that follows spontaneous action potentials, as has been observed in dopaminergic neurons of the ventral tegmental area (Appel et al., 2003). The hyperpolarization activated inward current $I_{\mathrm{h}}$, which is prominent in Golgi cells (Dieudonne, 1995, 1998), could also be a target of EtOH. Indirectly, EtOH could act by affecting inhibitory or excitatory input. Inhibitory input to these cells is provided by three classes of interneurons: the basket, stellate, and Lugaro cells. Basket and stellate cells provide pure GABAergic input, whereas Lugaro cells provide mixed GABAergic and glycinergic input (Dieudonne, 2001; Dumoulin et al., 2001). Therefore, it is possible that EtOH decreases this inhibitory input to Golgi cells via presynaptic or postsynaptic mechanisms, or both. This possibility does not seem likely given that most of the published evidence indicates that EtOH enhances GABAergic transmission in the CNS (Mihic, 1999; Aguayo et al., 2002; Roberto et al., 2003); however, an EtOH-induced decrease in glutamatergic input to basket, stellate, or Lugaro cells could indirectly decrease GABAergic tone, as we recently detected in interneuron-to-CA1 pyramidal neurons in the hippocampus (Carta et al., 2003). Alternatively, EtOH could increase excitatory input to Golgi cells, although evidence from a myriad of laboratories suggests that EtOH typically reduces glutamatergic input (Woodward, 1999; Dodd et al., 2000; Roberto et al., 2004). Moreover, we report here that $\mathrm{EtOH}$ does not affect spontaneous glutamate release at mossy fiber-to-granule cell synapses, suggesting that it is also ineffective at mossy fiber-to-Golgi cell synapses. Another possibility is that EtOH increases glutamatergic input at parallel fiberto-Golgi cell synapses. If this were the case, we would have expected to see a self-limited effect of EtOH because the increase in GABAergic tone at granule cells should eventually decrease glutamate release from parallel fibers (Hamann et al., 2002). Clearly, future studies will be required to determine the precise direct and indirect mechanisms by which EtOH alters the excitability of Golgi cells.

In conclusion, our findings demonstrate that EtOH increases GABAergic inhibition of cerebellar granule cells via an increase in Golgi cell firing. Our results are in agreement with those obtained in the pioneering study of Freund et al. (1993), who found that local application of EtOH to cerebellar slices increased firing of a cerebellar interneuron that was tentatively identified as a Golgi cell. Our results add to growing evidence indicating that the mechanism of action of EtOH in a number of regions of the CNS involves not only effects on postsynaptic inhibitory receptors but also on the release of the neurotransmitters that activate these receptors (Crowder et al., 2002; Melis et al., 2002; Carta et al., 2003; Roberto et al., 2003, 2004; Sebe et al., 2003; ZiskindConhaim et al., 2003).

\section{References}

Aguayo LG, Peoples RW, Yeh HH, Yevenes GE (2002) GABA(A) receptors as molecular sites of ethanol action. Direct or indirect actions? Curr Top Med Chem 2:869-885.

Aitken PG, Breese GR, Dudek FF, Edwards F, Espanol MT, Larkman PM, Lipton P, Newman GC, Nowak Jr TS, Panizzon KL, Raley-Susman KM, Reid KH, Rice ME, Sarvey JM, Schoepp DD, Segal M, Taylor CP, Teyler TJ, Voulalas PJ (1995) Preparative methods for brain slices: a discussion. J Neurosci Methods 59:139-149.

Appel SB, Liu Z, McElvain MA, Brodie MS (2003) Ethanol excitation of dopaminergic ventral tegmental area neurons is blocked by quinidine. J Pharmacol Exp Ther 306:437-446. 
Carta M, Ariwodola OJ, Weiner JL, Valenzuela CF (2003) Alcohol potently inhibits the kainate receptor-dependent excitatory drive of hippocampal interneurons. Proc Natl Acad Sci USA 100:6813-6818.

Crowder TL, Ariwodola OJ, Weiner JL (2002) Ethanol antagonizes kainate receptor-mediated inhibition of evoked GABA(A) inhibitory postsynaptic currents in the rat hippocampal CA1 region. J Pharmacol Exp Ther 303:937-944.

Deitrich RA, Dunwiddie TV, Harris RA, Erwin VG (1989) Mechanism of action of ethanol: initial central nervous system actions. Pharmacol Rev 41:489-537.

Dieudonne S (1995) Glycinergic synaptic currents in Golgi cells of the rat cerebellum. Proc Natl Acad Sci USA 92:1441-1445.

Dieudonne S (1998) Submillisecond kinetics and low efficacy of parallel fibre-Golgi cell synaptic currents in the rat cerebellum. J Physiol (Lond) 510:845-866.

Dieudonne S (2001) Serotonergic neuromodulation in the cerebellar cortex: cellular, synaptic, and molecular basis. Neuroscientist 7:207-219.

Dodd PR, Beckmann AM, Davidson MS, Wilce PA (2000) Glutamatemediated transmission, alcohol, and alcoholism. Neurochem Int 37:509-533.

Dumoulin A, Triller A, Dieudonne S (2001) IPSC kinetics at identified GABAergic and mixed GABAergic and glycinergic synapses onto cerebellar Golgi cells. J Neurosci 21:6045-6057.

Freund RK, Palmer MR (1997) Beta adrenergic sensitization of gammaaminobutyric acid receptors to ethanol involves a cyclic AMP/protein kinase A second-messenger mechanism. J Pharmacol Exp Ther 280:1192-1200.

Freund RK, Wang Y, Palmer MR (1993) Differential effects of ethanol on the firing rates of Golgi-like neurons and Purkinje neurons in cerebellar slices in vitro. Neurosci Lett 164:9-12.

Hamann M, Rossi DJ, Attwell D (2002) Tonic and spillover inhibition of granule cells control information flow through cerebellar cortex. Neuron 33:625-633.

Harris RA, McQuilkin SJ, Paylor R, Abeliovich A, Tonegawa S, Wehner JM (1995) Mutant mice lacking the gamma isoform of protein kinase C show decreased behavioral actions of ethanol and altered function of gamma-aminobutyrate type A receptors. Proc Natl Acad Sci USA 92:3658-3662.

Kaneda M, Farrant M, Cull-Candy SG (1995) Whole-cell and singlechannel currents activated by GABA and glycine in granule cells of the rat cerebellum. J Physiol (Lond) 485:419-435.

Kondo S, Marty A (1998) Differential effects of noradrenaline on evoked, spontaneous and miniature IPSCs in rat cerebellar stellate cells. J Physiol (Lond) 509:233-243.

Kuenzi FM, Fitzjohn SM, Morton RA, Collingridge GL, Seabrook GR (2000) Reduced long-term potentiation in hippocampal slices prepared using sucrose-based artificial cerebrospinal fluid. J Neurosci Methods 100:117-122.

Lee RS, Smith SS, Chapin JK, Shimizu N, Waterhouse BD, Maddus BN, Woodward DJ (1995) Effects of systemic and local ethanol on responses of rat cerebellar Purkinje neurons to iontophoretically applied norepinephrine and gamma-aminobutyric acid. Brain Res 687:12-21.

Lin AM, Freund RK, Palmer MR (1991) Ethanol potentiation of GABAinduced electrophysiological responses in cerebellum: requirement for catecholamine modulation. Neurosci Lett 122:154-158.

Lin AM, Bickford PC, Palmer MR, Gerhardt GA (1993) Ethanol inhibits the uptake of exogenous norepinephrine from the extracellular space of the rat cerebellum. Neurosci Lett 164:71-75.

Lin AM, Freund RK, Hoffer BJ, Palmer MR (1994) Ethanol-induced depressions of cerebellar Purkinje neurons are potentiated by beta-adrenergic mechanisms in rat brain. J Pharmacol Exp Ther 271:1175-1180.

Maex R, Schutter ED (1998) Synchronization of Golgi and granule cell firing in a detailed network model of the cerebellar granule cell layer. J Neurophysiol 80:2521-2537.

Melis M, Camarini R, Ungless MA, Bonci A (2002) Long-lasting potentiation of GABAergic synapses in dopamine neurons after a single in vivo ethanol exposure. J Neurosci 22:2074-2082.

Mihic SJ (1999) Acute effects of ethanol on GABAA and glycine receptor function. Neurochem Int 35:115-123.

Palmer MR, Hoffer BJ (1990) GABAergic mechanisms in the electrophysiological actions of ethanol on cerebellar neurons. Neurochem Res $15: 145-151$
Poltl A, Hauer B, Fuchs K, Tretter V, Sieghart W (2003) Subunit composition and quantitative importance of GABAA receptor subtypes in the cerebellum of mouse and rat. J Neurochem 87:1444-1455.

Roberto M, Madamba SG, Moore SD, Tallent MK, Siggins GR (2003) Ethanol increases GABAergic transmission at both pre- and postsynaptic sites in rat central amygdala neurons. Proc Natl Acad Sci USA 100:2053-2058.

Roberto M, Schweitzer P, Madamba SG, Stouffer DG, Parsons LH, Siggins GR (2004) Acute and chronic ethanol alter glutamatergic transmission in rat central amygdala: an in vitro and in vivo analysis. J Neurosci 24:1594-1603.

Rossi DJ, Hamann M (1998) Spillover-mediated transmission at inhibitory synapses promoted by high affinity alpha6 subunit GABA(A) receptors and glomerular geometry. Neuron 20:783-795.

Rossi DJ, Hamann M, Attwell D (2003) Multiple modes of GABAergic inhibition of rat cerebellar granule cells. J Physiol (Lond) 548:97-110.

Saxena NC, Macdonald RL (1996) Properties of putative cerebellar gammaaminobutyric acid A receptor isoforms. Mol Pharmacol 49:567-579.

Schuckit MA, Klein J, Twitchell G, Smith T (1994) Personality test scores as predictors of alcoholism almost a decade later. Am J Psychiatry 151:1038-1042.

Sebe JY, Eggers ED, Berger AJ (2003) Differential effects of ethanol on GABA(A) and glycine receptor-mediated synaptic currents in brain stem motoneurons. J Neurophysiol 90:870-875.

Shuttleworth CW, Connor JA (2001) Strain-dependent differences in calcium signaling predict excitotoxicity in murine hippocampal neurons. J Neurosci 21:4225-4236.

Sigel E, Baur R (2000) Electrophysiological evidence for the coexistence of alphal and alpha6 subunits in a single functional GABA(A) receptor. J Neurochem 74:2590-2596.

Sundstrom-Poromaa I, Smith DH, Gong QH, Sabado TN, Li X, Light A, Wiedmann M, Williams K, Smith SS (2002) Hormonally regulated alpha(4)beta(2)delta GABA(A) receptors are a target for alcohol. Nat Neurosci 5:721-722.

Tia S, Wang JF, Kotchabhakdi N, Vicini S (1996) Developmental changes of inhibitory synaptic currents in cerebellar granule neurons: role of GABA(A) receptor alpha 6 subunit. J Neurosci 16:3630-3640.

Tyrrell T, Willshaw D (1992) Cerebellar cortex: its simulation and the relevance of Marr's theory. Philos Trans R Soc Lond B Biol Sci 336:239-257.

Wall MJ, Usowicz MM (1997) Development of action potential-dependent and independent spontaneous GABAA receptor-mediated currents in granule cells of postnatal rat cerebellum. Eur J Neurosci 9:533-548.

Wallner M, Hanchar HJ, Olsen RW (2003) Ethanol enhances $\alpha_{4} \beta_{3} \delta$ and $\alpha_{64} \beta_{3} \delta \gamma$-aminobutyric acid type A receptors at low concentrations known to affect humans. Proc Natl Acad Sci USA 100:15218-15223.

Watanabe D, Inokawa H, Hashimoto K, Suzuki N, Kano M, Shigemoto R, Hirano T, Toyama K, Kaneko S, Yokoi M, Moriyoshi K, Suzuki M, Kobayashi K, Nagatsu T, Kreitman RJ, Pastan I, Nakanishi S (1998) Ablation of cerebellar Golgi cells disrupts synaptic integration involving GABA inhibition and NMDA receptor activation in motor coordination. Cell 95:17-27.

Weiner JL, Zhang L, Carlen PL (1994) Potentiation of GABAA-mediated synaptic current by ethanol in hippocampal CA1 neurons: possible role of protein kinase C. J Pharmacol Exp Ther 268:1388-1395.

Weiner JL, Valenzuela CF, Watson PL, Frazier CJ, Dunwiddie TV (1997) Elevation of basal protein kinase $\mathrm{C}$ activity increases ethanol sensitivity of GABA(A) receptors in rat hippocampal CA1 pyramidal neurons. J Neurochem 68:1949-1959.

Woodward JJ (1999) Ionotropic glutamate receptors as sites of action for ethanol in the brain. Neurochem Int 35:107-113.

Yang X, Criswell HE, Breese GR (1999) Action of ethanol on responses to nicotine from cerebellar Purkinje neurons: relationship to methyllycaconitine (MLA) inhibition of nicotine responses. Neurochem Int 35:185-194.

Yang X, Criswell HE, Breese GR (2000) Ethanol modulation of gammaaminobutyric acid (GABA)-mediated inhibition of cerebellar Purkinje neurons: relationship to GABAb receptor input. Alcohol Clin Exp Res 24:682-690.

Ziskind-Conhaim L, Gao BX, Hinckley C (2003) Ethanol dual modulatory actions on spontaneous postsynaptic currents in spinal motoneurons. J Neurophysiol 89:806-813. 